\title{
Role of Institutional Interaction for Financial Stability in the context of Inflation Targeting
}

\author{
Abderrazak El Hiri \\ Professor at University Sidi Mohamed Ben Abdellah. Director of the Laboratory for \\ Coordination of Studies and Research in Economic Analysis and Forecasting (CERAPE) \\ Salwa Habiby \\ PhD student at University Sidi Mohamed Ben Abdellah, CERAPE.
}

\begin{abstract}
The Moroccan authorities are aiming for the implementation of an inflation targeting policy. However, the economy has a number of handicaps, including a high level of debt and modest financial stability. The purpose of this article is to analyze how the interaction between institutions could enhance financial stability and manage risks that could disrupt the smooth functioning of the market as part of an inflation-targeting regime, across two empirical studies. After studying the interaction between policies, we have developed a model of structural equations that integrates the specificities of the Moroccan economy and its institutions into a predictive vision. We found that the weight of debt influences negatively the financial market, but an application of inflation targeting can mitigate the severity of the financial and debt crisis on financial stability while keeping inflation and production close to their objectives. The results of this study encourage the transition in a medium-term to inflation targeting policy, since reducing the level of debt influence positively the expectations of economic agents.
\end{abstract}

Keywords: financial stability, fiscal policy, inflation targeting, structural equation model.

\section{INTRODUCTION}

In recent years, the emphasis on financial stability has grown. It should be noted that inflationtargeting countries are facing new challenges. On the one hand, they must combine the two objectives of monetary and financial stability- without forgetting the interdependence between the two policies- and the risk arising from the integration of the two objectives in the monetary policy rule. On the other hand, they must take into account the tax objective. However, opinions on the fallout from fiscal instability differ. For some, the application of a fiscal rule is necessary since a large fiscal deficit could lead to an overreaction of inflation expectations and therefore to higher inflation. For others, the introduction of the fiscal target will have no impact on financial stability and may even degrade it.

The discussions that followed the latest financial crisis have shown that the dichotomy between monetary policy, financial stability policy, and fiscal policy may not exist since they are intrinsically linked.

It is in the context of these discussions and the increase in the number of countries adopting the targeting and fiscal rule policy that this work is taking place.

Indeed, Morocco wants to adopt an inflation targeting policy, but the economy suffers from a high level of debt and relative financial stability. 
The issues that arise and to which we will answer are: can Morocco adopt a targeting policy without having fiscal stability? Will the level of debt deteriorate financial stability? What is the combination, in the context of inflation targeting, between fiscal and monetary policies to ensure financial stability?

To answer these questions we will perform two empirical analyzes. The first is an analysis of the interaction between fiscal, monetary, financial and social policy. The second is a study of the possible implementation of the inflation targeting policy in Morocco, using a structural equation model.

\section{INTERACTION BETWEEN INSTITUTIONS FOR FINANCIAL STABILITY: LITERATURE REVIEW}

The question of interaction between financial stability and monetary policy has attracted the interest of several theorists. Indeed, Cogley [1] has shown that since it is almost impossible for policymakers to check speculative activity around asset prices, any attempt to break through asset bubbles would instead destabilize the economy. Contrary to this result, Stone [2] asserts using a New Keynesian model that the central bank should consider asset prices when designing monetary policy, the reaction to asset prices will not induce additional volatility in the economy. Borio et al. [3] have listed the indicators that have a predictive value to be included in the rule to improve our ability to measure the risks of a financial crisis.

For Woodford [4] the real issue is not whether assets are under / over-rated, but rather the regulators need to monitor the extent to which positions taken by leveraged institutions pose a risk to financial stability. The most worrying issue is the likelihood of a poor common outcome that could trigger a systemic crisis. The central bank must balance financial stability objectives with its goal of price stability in a flexible inflation targeting commitment. This can be done by directly adjusting how central banks targeting inflation already envision the short-term tradeoff between price stability and production stability.

Svensson [5], meanwhile, proposes that monetary and macroprudential policies should be conducted separately. The impact of each goal on the other should be unforeseen and weak. In addition, coordination with other macro-prudential instruments is important to avoid negative interaction effects, especially if they serve different intermediate objectives. This will allow the achievement of the Nash equilibrium, namely low inflation and acceptable financial stability.

However, the integration of the objective of financial stability into the loss function poses the problem of independence of the central bank, a legitimate notion in the sharing of monetary and fiscal responsibilities, as well as in the conduct of micro and macro-prudential measures [6]. 
Figure 1: Public debt as a percentage of GDP and the budget balance of a sample of countries at the date of adoption of the inflation-targeting regime.

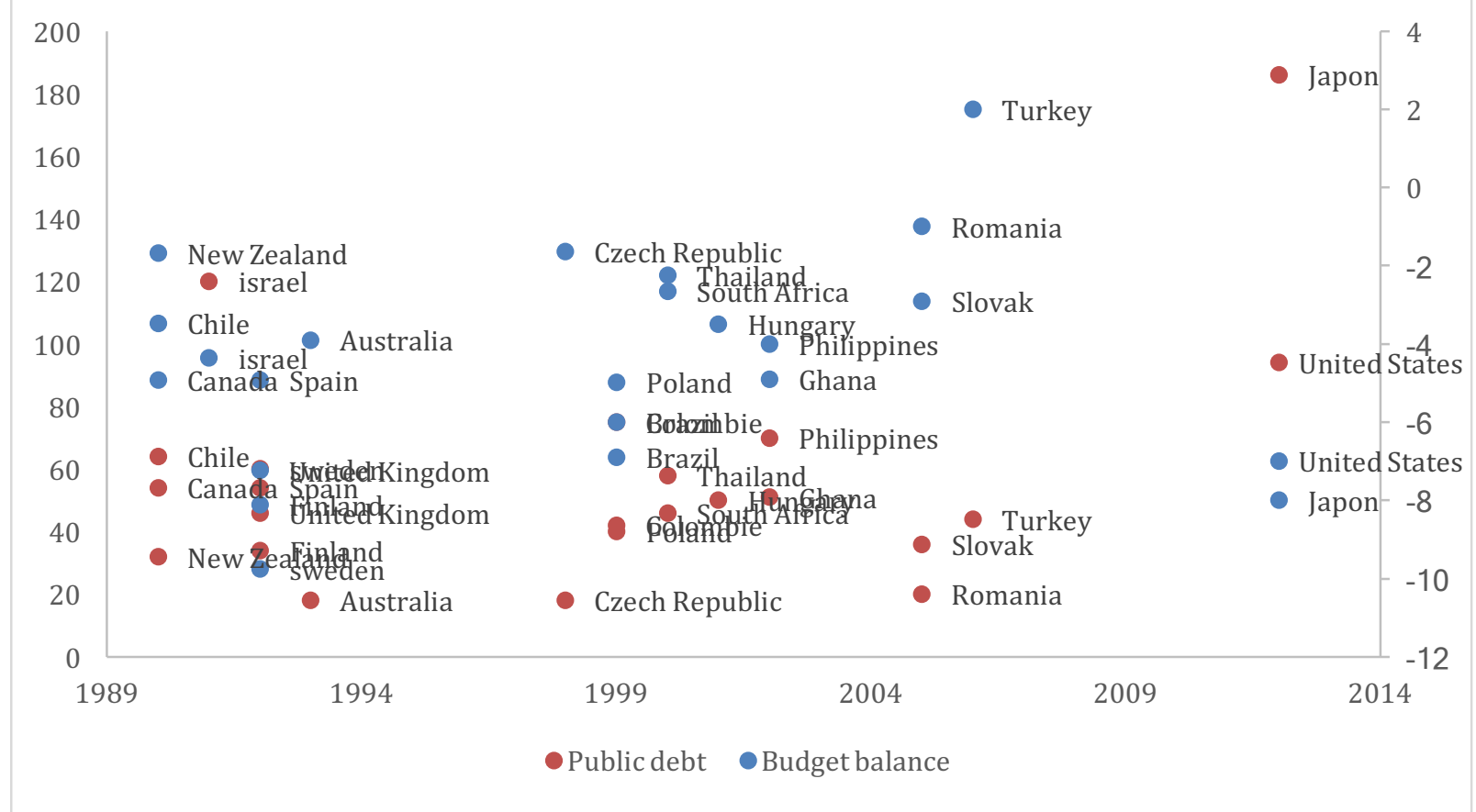

Source: International Monetary Fund, Abbas, Belhocine, El-Ganainy \& Horton (2011) [7], Amato \& Gerlach (2002) [8] and author's calculation.

The interaction between monetary policy and fiscal balance still raises a number of questions among theoreticians and practitioners. Indeed, for Mishin [9], fiscal stability is not a strong precondition for adopting an inflation-targeting regime. Indeed, as shown in the figure below, the condition of a sound fiscal policy when inflation targeting was adopted was often violated. The rush in which the introduction of the inflation-targeting regime and the instability of the economic and fiscal environment have forced many central banks to not have an econometric model or fiscal rule before the adoption of targeting.

The influence of inflation targeting on the possibility of adopting a fiscal rule has attracted the interest of several researchers. For Batini [10], inflation-targeting countries saw a sharp reduction in their budget spending after the adoption of inflation targeting, which confirms the government's commitment to the new regime. Lucotte [11] has shown that the independence of the central bank and the maintenance of inflation at a sufficiently low level are two factors likely to influence the decision to adopt fiscal rules since they motivate the government of emerging economies to improve. the collection of domestic tax revenues to offset the loss of seigniorage income. Contrary to the results of these studies, an IMF [12] survey of a number of emerging and developed countries showed that the application of a fiscal rule must be made before the adoption of an inflation-targeting regime. This sequence of budget reform and joint targeting is likely to yield better results on fiscal behavior, the level of inflation and the credibility of the inflation targeting policy.

Regardless of this order of succession, and despite the fact that the number of countries applying budget targeting is steadily increasing (see appendix), the views on the impact of adopting a fiscal rule seem rather divided in the empirical literature.

For some authors, the targeting of the fiscal balance or the public debt could contribute to reducing the pressure on primary expenditure due to income shocks if the political and institutional costs of the non-compliance are large enough [13], leading to a consolidation. 
Success [14], and could have a significant, robust and quantitative effect on the limitation of the public deficit [15]. However, for others, the implementation of fiscal rules has had no positive impact on country performance; measured by the volatility of the primary fiscal balance; who adopted it compared to those who did not [16]. For a fiscal rule to be effective and adapt to unforeseeable situations, it must be complemented by strong political commitment or by national budget institutions [17].

For Mishin, the doubt over the implementation of measures and regulations to conduct a sound and responsible fiscal policy was decided after the financial crisis [18]. In a difficult economic environment, the central bank will not be able to control the target level of inflation without long-term fiscal sustainability. When the banking and financial system is underdeveloped, the government exerts a tax burden on monetary policy to finance the public deficit. This can lead to either fiscal dominance, the production of a state default, or financial disruption and a contraction of the economy.

Co-ordination between fiscal and monetary policy can therefore lead to a stable financial system, but at the same time respecting a certain proportion, since excessive public debt can deteriorate the financial and economic sphere and lead to a crisis.

\section{ASSESSMENT OF THE INTERDEPENDENCE BETWEEN FINANCIAL, MONETARY, MACROECONOMIC, FISCAL AND SOCIAL STABILITY}

The possible implementation of inflation targeting in Morocco leads us to perform an analysis of the interaction of price stability, financial and budgetary stability to assess the challenges and issues to be addressed for the transition to the new regime.

The depth of the financial sector and the level of the budget deficit have improved considerably in the last decade. We will outline some indicators to assess this improvement and identify weaknesses to be overcome for effective implementation of the inflation targeting policy.

\section{Risk specification}

Financial stability risk mapping is composed of indicators from financial institutions, macroeconomic and financial conditions as well as economic actors.

Figure 2: Mapping of risks to financial stability.
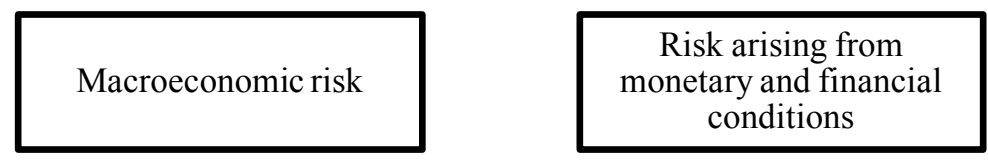

Credit risk
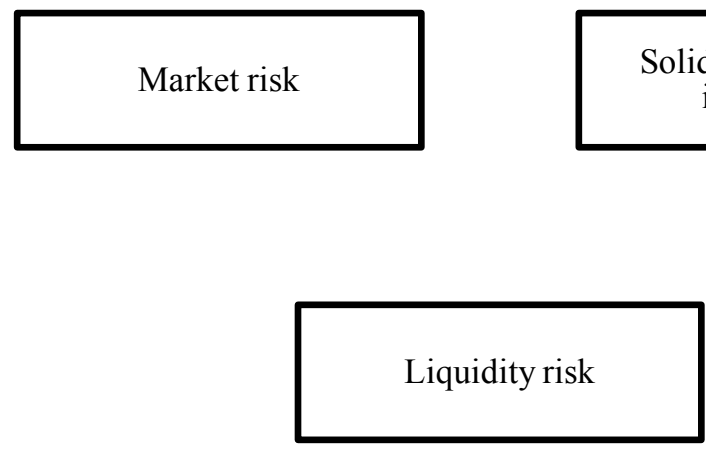

Real estate risk

Source: Bank Al Maghrib. 


\section{Results and discussion}

We will simultaneously present the results and discussion of interactions between policies.

\section{Financial stability Vs macroeconomic stability Vs social stability}

The comparison between the credit / GDP ratio and the output gap allows us to compare between financial and economic development. The figure below shows that the long-term trend in the credit / GDP ratio goes with the output gap, which means that there is no conflict of objectives between financial and macroeconomic stability.

Figure 3: Comparison between financial market development and the output gap.

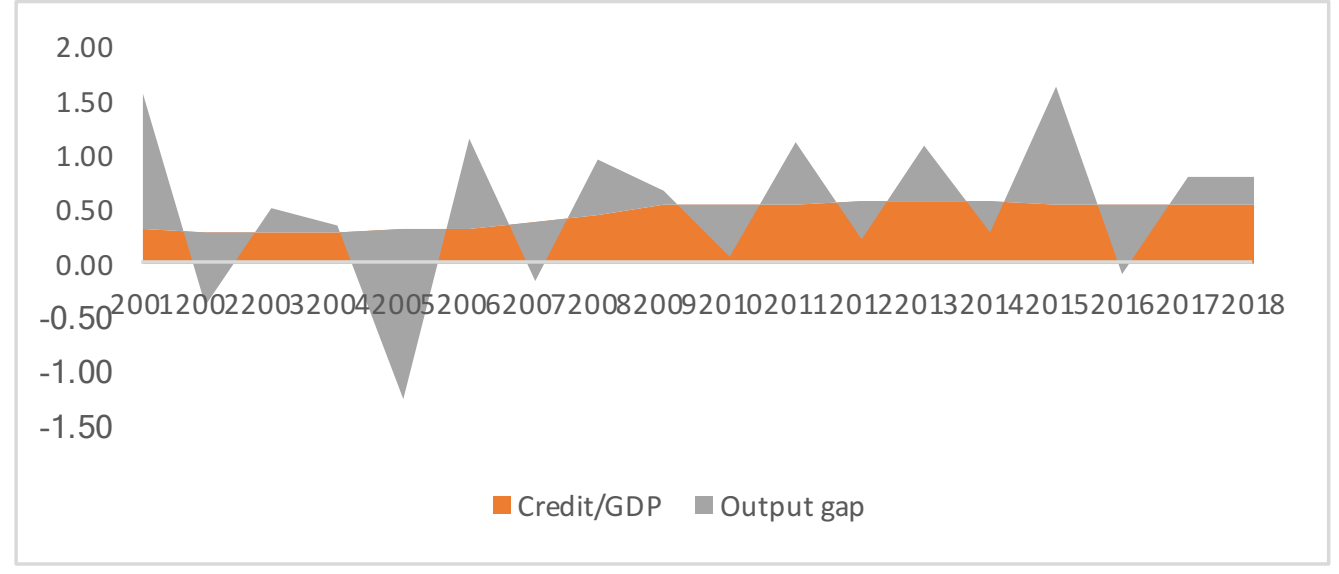

Source: Bank Al Maghrib and author's calculations.

The undeveloped financial markets are often located in emerging countries. Indeed, if we compare the ratio foreign direct investment / GDP with the unemployment rate and real GDP growth, we find that they have the same trend.

Well-functioning financial systems provide quality and easily accessible information, which can reduce transaction costs and, subsequently, improve resource allocation and stimulate economic growth. Banking systems and stock markets reinforce growth, the main factor in reducing poverty.

Without forgetting the impact of legislative and political stability (investment risk) that made the existence and development of financial markets possible. Investors are starting to have more and more confidence in investing in our country. 
Figure 4: Comparison of real GDP growth in percentage, the unemployment rate, and the foreign investment / GDP ratio.

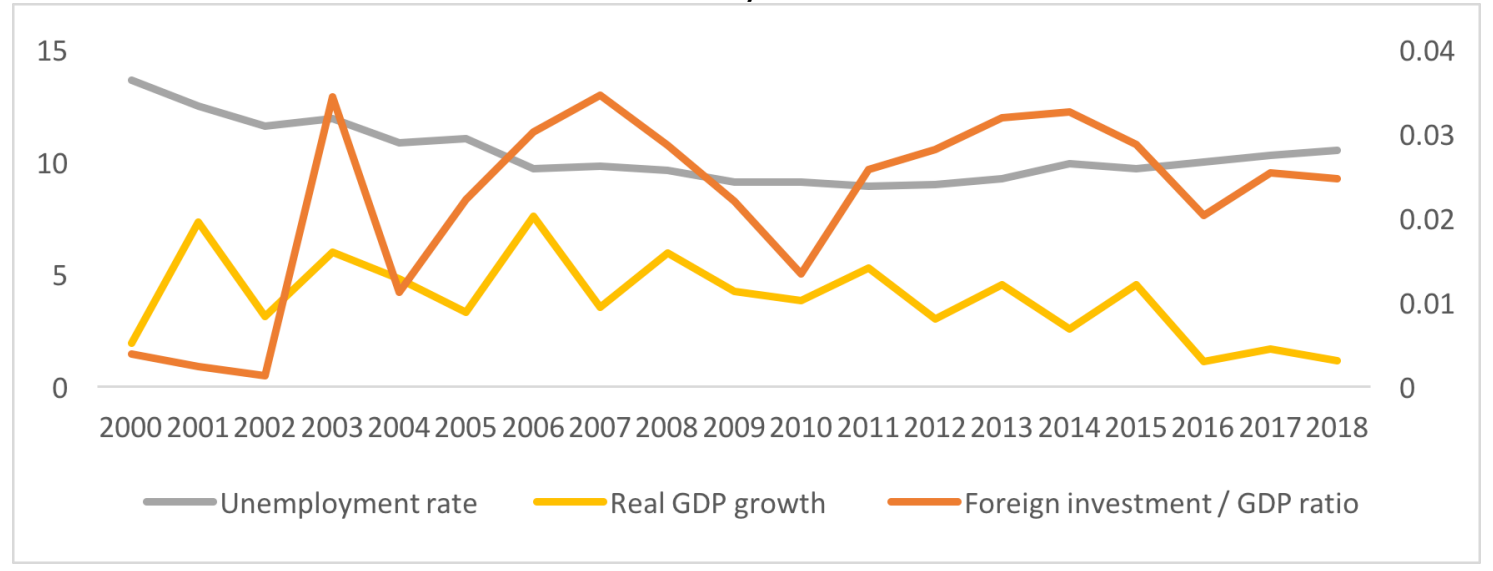

Source: World Perspective and World Bank.

\section{Financial stability Vs monetary stability}

In countries where monetary policy is unstable, financial markets are not developed. Indeed, a monetary policy based on controlled inflation, a balanced exchange rate, a stable and lower credit rate ensures access to loans and the capital market, hence the development of the financial market.

Figure 5: Relationship between financial stability and monetary stability.

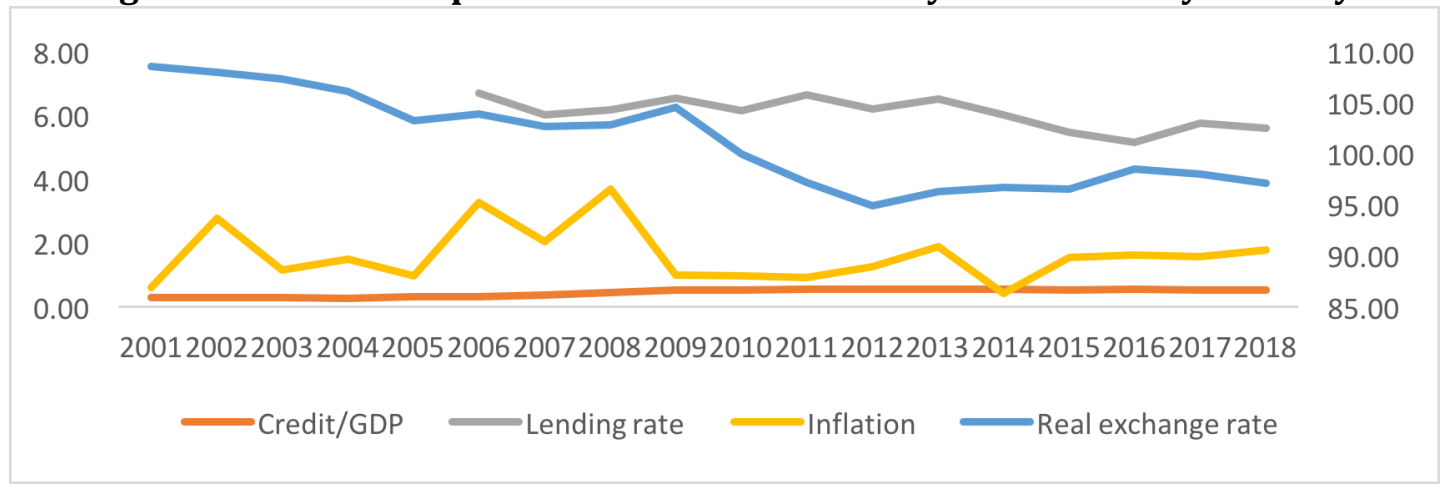

Source: Bank Al Maghrib.

\section{Financial stability Vs fiscal stability}

The balance of payments reflects the health of an economy since it summarizes a country's economic transactions with the rest of the world. It shows the balance of a country's international payment and its international investment position. A country where the financial market is developed, and where there is an investment flow, presents a healthy economy. 
Figure 6: Balance of payments in billion dirhams and the development of the financial market.

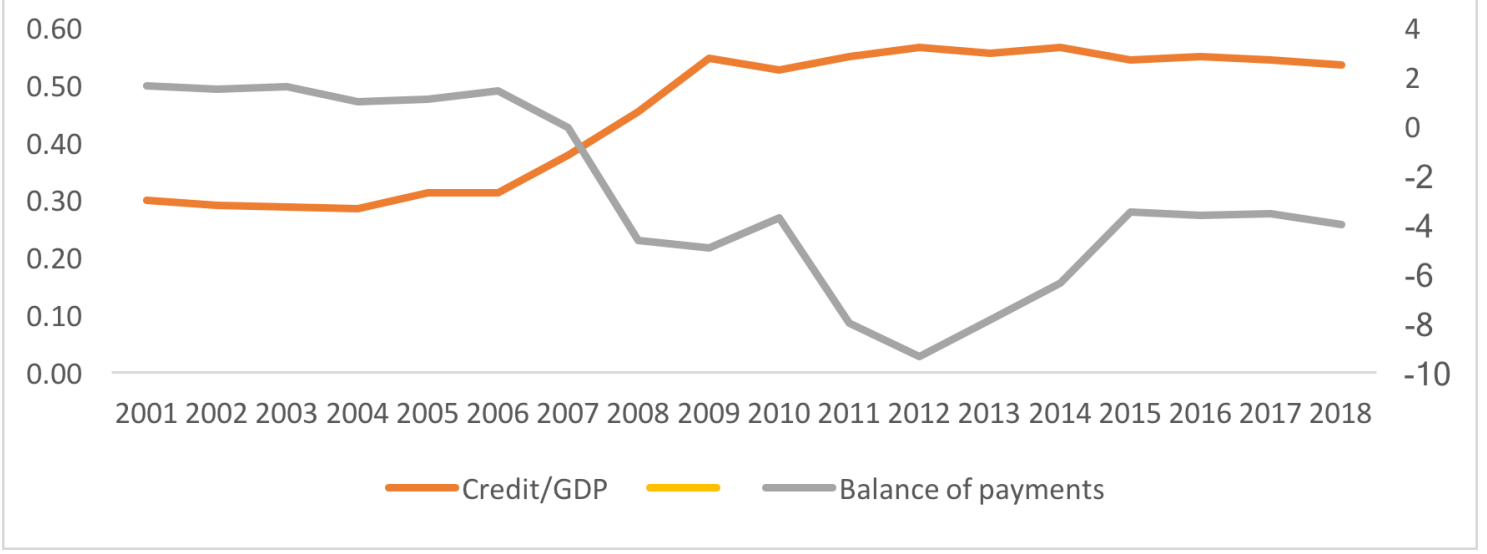

Source: IMF.

Figure 7: Evolution of domestic debt and public debt.

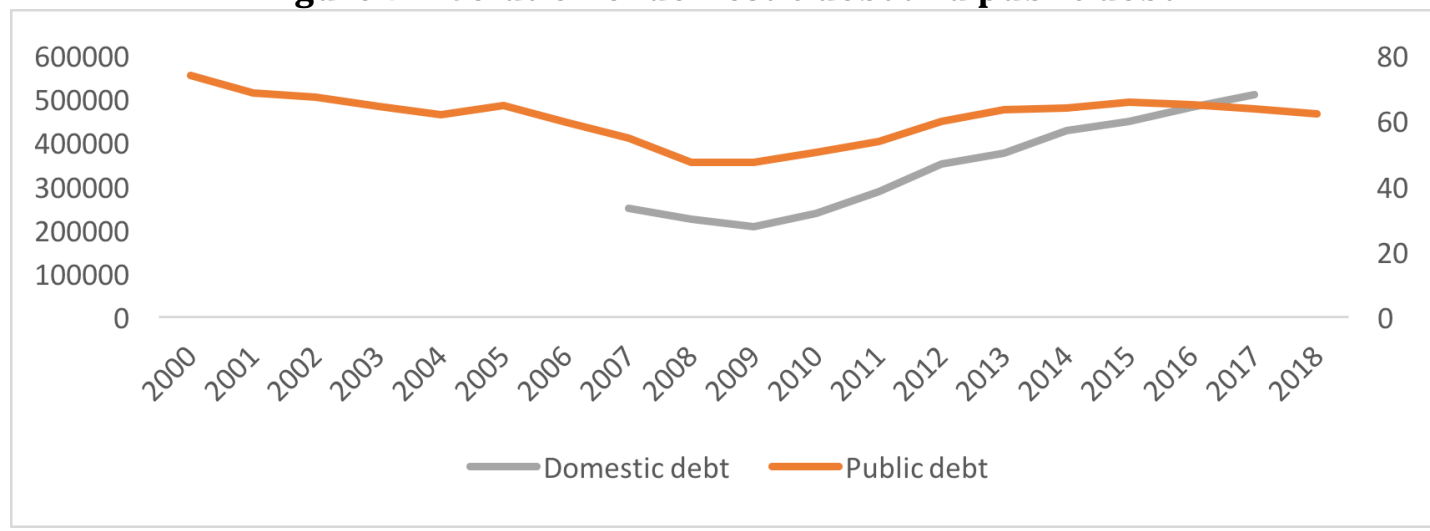

Source: Ministry of Economy and Finance.

Despite the efforts made in terms of public finances, the budget deficit worsened as it went from $2 \%$ of GDP in 2006 to 4\% of GDP in 2017. While national savings improved by $14 \%$ in 2017 to ensure self-financing and investment expenditures.

Public debt and domestic debt account respectively for $62 \%$ and $40 \%$ of GDP. The growth of domestic debt is dangerous because of the crowding out effect. In addition, the level of indebtedness in currency is very high; it remains one of the big challenges to be taken up for the passage towards a policy of inflation targeting [19].

\section{ECONOMETRIC STUDY OF THE IMPACT OF GOVERNMENT DEBT ON FINANCIAL STABILITY UNDER THE INFLATION-TARGETING REGIME}

Since the State's debt is a hindrance to the adoption of an inflation targeting policy in Morocco, the aim of this paragraph is to analyze the influence of the budget deficit on the occurrence of financial and economic crises, and to investigate to what extent flexible targeting monetary decisions with debt and credit spread objective could influence financial stability.

To address this issue, we will develop a structural equation model built in steps underperformed Schumacker and Lomax [20].

\section{Model specification}

Based on the theories already advanced, we will build a model of structural equations (SEM) that will allow us to trace the linear relationships between the objectives of flexible targeting 
(inflation and production), fiscal stability and financial stability, as well as the verification of the hypotheses of interactions in a predictive vision.

The variables of the research model concern:

- Monetary policy: the variable that reflects the shift of monetary policy is the interest rate. It is calculated according to prospective Taylor rule which includes real interest rate, inflation target, production $\left(\mathrm{x}_{\mathrm{t}}\right)$, and credit spread: $\mathrm{i}_{\mathrm{t}}=\mathrm{p} \mathrm{i}_{\mathrm{t}-1}+(1-\mathrm{p}) \mathrm{r}^{*}+\alpha\left(\boldsymbol{\pi}_{\mathrm{t}}(\mathbf{p t + 1})-\boldsymbol{\pi}^{*}\right)$ $+\beta \mathrm{x}_{\mathrm{t}}+\boldsymbol{\varphi}$ CS.

Credit spread measures the severity of credit frictions. Adding this variable to the Taylor rule means adding the purpose of reducing the incidence of financial crises.

- Fiscal policy: the stability of fiscal policy is measured by the public debt percentage GDP. The financing of the budget deficit is made through borrowing from the financial market or seignorage.

- The stability of the financial market measured by domestic credit percentage GDP. We chose this indicator since it could be coordinated with the stabilization of inflation and output [21]. Banks' ability to cope with extreme shocks is measured by the stress test.

Figure 8: Latent variables that make up the internal model.

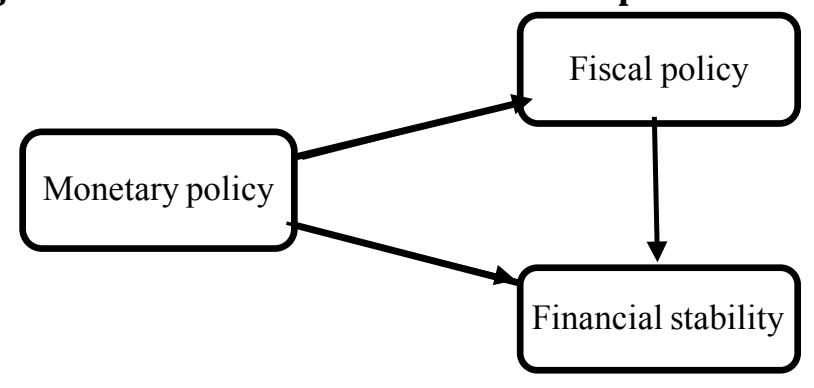

In this figure, fiscal policy has a mediating effect. In the next section, we will also test its moderating effect when we include the tax objective in the Taylor rule. The objective is to know whether the strength of the relationship between monetary and financial policy depends on the target level of fiscal stability. In other words, the balance between monetary and fiscal policy to financial stability.

Note that the manifest variables (the external model or measurement) are standardized and related to the latent variable in a reflective way.

We have opted for partial least squares (PLS) for two main reasons: the sample size is less than 100 (quarterly data from Q1.2000 to Q2.2018); and since we want to test the impact on the stability of asset prices if Morocco is part of an inflation targeting policy with fiscal policy.

\section{Results of estimates}

Following the method described by Chin [22], Tenenhaus et al [23], we estimated latent variable scores with an iterative logarithm, and then we used multiple regression. 
Figure 9: Causal PLS model (structural and external model).

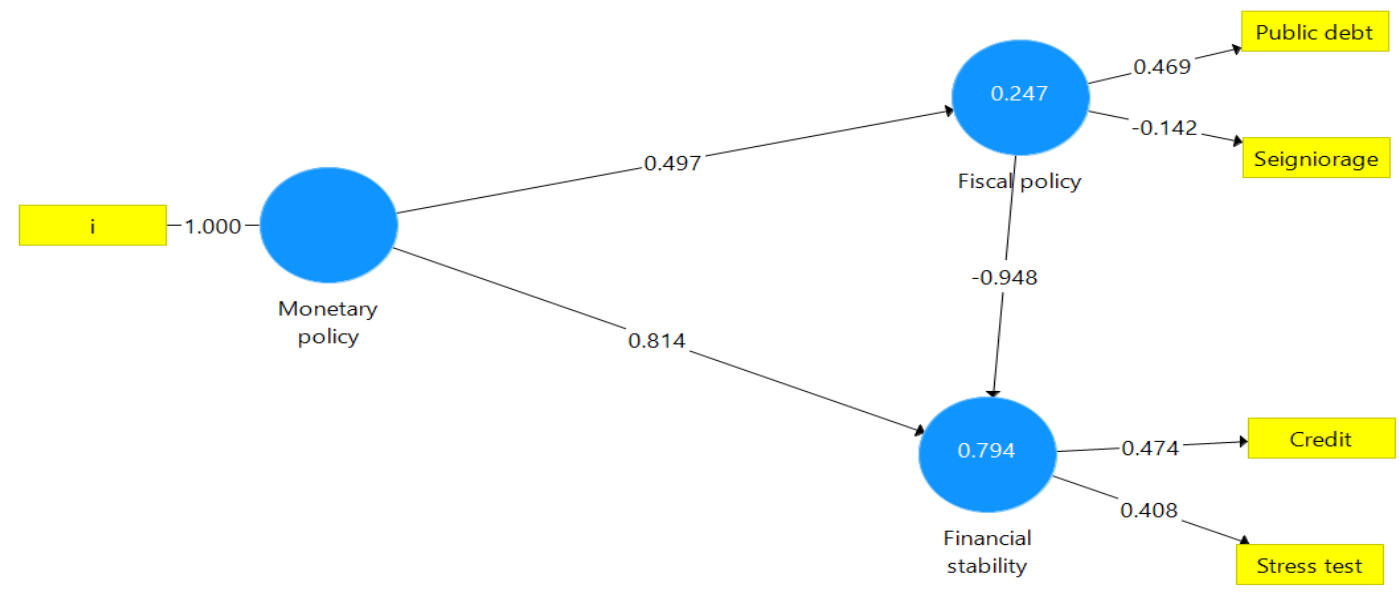

The results of the causal model are summarized in the following tables:

\begin{tabular}{|c|c|c|}
\hline Latent variable & Manifest variables & Correlation \\
\hline Monetary Policy & Interest rate & 1 \\
\hline \multirow{2}{*}{ fiscal Policy } & Public debt\% GDP & 0,469 \\
\cline { 2 - 3 } & seigniorage & $-0,142$ \\
\hline \multirow{2}{*}{ Financial stability } & Credit\% GDP & 0,474 \\
\cline { 2 - 3 } & Stress test & 0,408 \\
\hline
\end{tabular}

Table 1: Results of external model estimation.

- For the financial stability variable, we have $\mathrm{R}^{2}=0.794$ and the $\mathrm{R}^{2}$ Bootstrap $=0.798$.

- All the Collinearity Statistics (VIF) are less than three.

- The path coefficient (internal model) is:

\begin{tabular}{|c|c|c|}
\hline Latent variable & Path coefficient & P-value \\
\hline Monetary policy - financial stability & 0,814 & 0,006 \\
\hline Monetary policy - fiscal policy & 0,497 & 0,035 \\
\hline Fiscal Policy - Financial Stability & $-0,948$ & 0,013 \\
\hline
\end{tabular}

Table 2: Results of Internal Model Estimation.

After introducing the tax objective into the Taylor rule, we calculated the PLS interaction. The result is:

\begin{tabular}{|c|c|c|}
\hline Latent variable & Coefficient & Probability \\
\hline Monetary policy - financial stability & 0,944 & 0,047 \\
\hline
\end{tabular}

Table 3: verification of the moderating effect of the public debt \% GDP.

\section{Discussion}

At the end of our analysis, we can make the following conclusions:

First, the weight of monetary financing (seigniorage) is lower than borrowing from the financial market, which means that the Moroccan government does not use the net income from money creation to bridge the transitional gap between income and expenditure flows. This level of deficit poses no threat to an independent monetary policy operated by the central bank. In parallel with fiscal consolidation measures, monetary policy is in most cases neutral or 
expansionary in order to reach the target level of inflation and encourage the granting of credit. However, to avoid fiscal dominance and tax-based inflation, government financing from the financial market must not be exuberant.

Second, fiscal policy has a negative and relatively strong effect on financial stability. For a successful transition to the inflation targeting policy, we must reduce the debt level to preserve stability.

Finally, monetary policy may have a slight impact on the dynamics of the public debt, in particular by its influence on the interest rate, but it has a strong and positive influence on financial stability.

Based on these findings, we tested the impact of the combination of monetary and fiscal policy on financial stability. The result is promising. Indeed, because the inflation target is set in principle in coordination between Bank Al Maghrib and the Ministry of Finance, the independence of the central bank is ensured. In addition to this coordination, there is a balance between expected inflation, production, and prevention of financial crises.

\section{CONCLUSION AND RECOMMENDATION}

The financial crisis has shown that to avoid persistent economic shocks, enhance financial stability and macroeconomic conditions, the central bank must consider the macro-prudential measures in the formulation of monetary policy. But the success of this process depends heavily on the level of public debt since it determines the level of agreement between institutions and the possible combination of objectives.

Bank Al Maghrib invested increasingly to introduce the issues of financial stability in its monetary behavior. Besides the latest reform of the statutes focused on strengthening the openness of the economy to limit the severity of financial crises.

In this article, we analyzed the interaction between institutions to strengthen financial stability and manage risks that could disrupt the proper functioning of the market under an inflationtargeting regime.

In a first study, we analyzed the interaction between policies. We have demonstrated the importance of financial stability and its link to fiscal, monetary and economic growth. On the one hand, financial stability facilitates the transfer of capital that is necessary for growth. On the other hand, good economic conditions ensure good investment returns and reduce the risk of financial destabilization. Thus, a country where the financial market is developed, the volume of the investments increases which facilitates the increase of the production and the consumption. This growth leads to the reduction of the unemployment rate. We have also raised the problem of public debt and the size of the balance of payments on financial stability. In a second study, this time econometrically, we tested the desirability of applying an inflationtargeting regime in light of the lessons of the 2009 financial crisis. An application of inflation targeting can mitigate the severity of the financial crisis and debt on financial stability while keeping inflation and production levels close to their objectives. The results of this study encourage the transition to a medium-term inflation targeting policy, since reducing the level of indebtedness is desirable before targeting influence positively the expectations of economic agents. 


\section{References}

Cogley, T. (1999). Should the Fed take deliberate steps to deflate asset price bubbles?. Economic Review-Federal Reserve Bank of San Francisco, (1), 42.

Stone, S. (2009). Asset Prices, Monetary Policy and Macroeconomic Stability.

Borio, C. E., \& Drehmann, M. (2009). Assessing the risk of banking crises-revisited.

Woodford, M. (2012). Inflation targeting and financial stability (No. w17967). National Bureau of Economic Research.

Svensson, L. E. (2015). Monetary policy and macroprudential policy: different and separate. Canadian Journal of Economics.

Clerc, L. \& Raymond, R. (2014). Les banques centrales et la stabilité financière : nouveau rôle, nouveau mandat, nouveaux défis ?. Revue d'économie financière, 113,(1), 193-214. doi:10.3917/ecofi.113.0193.

Abbas, S. A., Belhocine, N., El-Ganainy, A., \& Horton, M. (2011). Historical patterns and dynamics of public debtevidence from a new database. IMF Economic Review, 59(4), 717-742.

Amato, J. D., \& Gerlach, S. (2002). Inflation targeting in emerging market and transition economies: Lessons after a decade. European Economic Review, 46(4-5), 781-790.

Mishkin, F. S. (2004). Can inflation targeting work in emerging market countries? (No. w10646). National Bureau of Economic Research.

Batini, N. (2006). Under what conditions can inflation targeting be adopted? The experience of emerging markets," Central Bank of Chile Working Papers no.

Lucotte, Y. (2012). Adoption of inflation targeting and tax revenue performance in emerging market economies: An empirical investigation. Economic Systems, 36(4), 609-628.

Combes, J. L., Debrun, M. X., Minea, A., \& Tapsoba, R. (2014). Inflation Targeting and Fiscal Rules: Do Interactions and Sequencing Matter? (No. 14-89). International Monetary Fund.

Wierts, P. (2007, December). Can Expenditure Rules Counter Expenditure Pressures from Revenue Windfalls?. In Paper for the ECB Public Finance Workshop of (Vol. 6).

Guichard, S., Kennedy, M., Wurzel, E., \& André, C. (2007). What Affects Fiscal Consolidation?-Some Evidence from OECD Countries.

Debrun, X., Moulin, L., Turrini, A., Ayuso-i-Casals, J., \& Kumar, M. S. (2008). Tied to the mast? National fiscal rules in the European Union. Economic Policy, 23(54), 298-362.

Medina, L., Caceres, C., \& Corbacho, M. A. (2010). Structural Breaks in Fiscal Performance: Did Fiscal Responsibility Laws Have Anything to Do with Them? (No. 10-248). International Monetary Fund.

Wyplosz, C. (2012). Fiscal rules: Theoretical issues and historical experiences. In Fiscal policy after the financial Crisis(pp. 495-525). University of Chicago Press.

Mishkin, F. S. (2017). Rethinking monetary policy after the crisis. Journal of International Money and Finance, 73, $252-274$

SAIDI A. (2017). Perspectives d'adoption du ciblage de l'inflation au Maroc. Journées Internationales de Macroéconomie et de Finance. Bank Al Maghrib. URL : http://www.bkam.ma/Seminaires-et-conferences/2017

Lomax, R. G., \& Schumacker, R. E. (2004). A beginner's guide to structural equation modeling. psychology press.

Akram, Q. F., \& Eitrheim, Ø. (2008). Flexible inflation targeting and financial stability: Is it enough to stabilize inflation and output?. Journal of Banking \& Finance, 32(7), 1242-1254.

Chin, W. W. (1998). The partial least squares approach to structural equation modeling. Modern methods for business research, 295(2), 295-336.

Tenenhaus, M., Vinzi, V. E., Chatelin, Y. M., \& Lauro, C. (2005). PLS path modeling. Computational statistics \& data analysis, 48(1), 159-205. 


\section{APPENDIX: COUNTRY AND YEAR OF APPLICATION OF PUBLIC DEBT TARGETING}

$\begin{array}{ll}\text { Antigua and Barbuda } & 1998 \\ \text { Argentina } & 2000 \\ \text { Armenia } & 2008 \\ \text { Australia } & 1998 \\ \text { Austria } & 1995 \\ \text { Belgium } & 1992 \\ \text { Benin } & 1999 \\ \text { Brazil } & 2001 \\ \text { Bulgaria } & 2003 \\ \text { Burkina Faso } & 1999 \\ \text { Cameroon } & 2002 \\ \text { Canada } & 1998 \\ \text { Central African Republic } & 2002 \\ \text { Chad } & 2002 \\ \text { Congo, Rep. } & 2002 \\ \text { Cote d'Ivoire } & 1999 \\ \text { Czech Republic } & 2004 \\ \text { Denmark } & 1992 \\ \text { Dominica } & 1998 \\ \text { Ecuador } & 2003 \\ \text { Equatorial Guinea } & 2002 \\ \text { Estonia } & 2004 \\ \text { France } & 1992 \\ \text { Finland } & 1995 \\ \text { Gabon } & 2002 \\ \text { Germany } & 1992 \\ \text { Greece } & 1992 \\ \text { Grenada } & 1998 \\ \text { Guinea-Bissau } & 1999\end{array}$

Hungary

Indonesia

Ireland

Italy

Kenya

Latvia

Lithuania

Luxembourg

Mali

Malta

Mauritius

Namibia

Netherlands

Niger

Pakistan

Panama

Poland

Portugal

Romania

Senegal

Slovak Republic

Slovenia

Spain

Sri Lanka

St. Lucia

St. Kitts and Nevis

St. Vincent and the Grenadines

Togo

United Kingdom
2004

2004

1992

1992

1997

2004

1997

1990

1999

2004

2004

2001

1992

1999

2005

2002

1997

1992

2007

1999

2004

2004

1992

2003

1998

1998

1998

1999

1992

Source: Altunbaş, Y., \& Thornton, J. (2017). Why do countries adopt fiscal rules?. The Manchester School, 85(1), 65-87 